\title{
Udder Morphology Relationship with Milk Yield in Singlet and Twins Bearing Surti Goat
}

\author{
Krishna C. Gamit ${ }^{1 *}$, T.K.S. Rao ${ }^{2}$, B.J. Thakre ${ }^{3}$, V.V. Gamit ${ }^{1}$ and A.S. Patel ${ }^{1}$ \\ ${ }^{1}$ Department of Livestock Production Management, ${ }^{3}$ Department of Veterinary Parasitology, \\ College of College of Veterinary Science and Animal Husbandry, Junagadh Agricultural \\ University, Junagadh, India \\ ${ }^{2}$ Department of Livestock Production Management, College of Veterinary Science and \\ Animal Husbandry, Navsari Agricultural University, Navsari, India \\ *Corresponding author
}

\begin{tabular}{l} 
K e y w o r d s \\
$\begin{array}{l}\text { Surti goat, Signlet, } \\
\text { Twin, Kidding, } \\
\text { Udder }\end{array}$ \\
\hline Article Info \\
\hline $\begin{array}{l}\text { Accepted: } \\
\text { 12 July } 2019 \\
\text { Available Online: } \\
10 \text { August } 2019\end{array}$ \\
\hline
\end{tabular}

A B S T R A C T

The goat contributes $3.5 \%$ of the total milk and $19 \%$ of the total meat production in India. As Goat is called a poor man's cow because it provides milk, manure and protein source at low cost. Goat is gaining recognition in the backyard industry because of fewer space necessities and better efficiency than cattle's. Production performances supposed to vary with twin or singlet kidding in goats. The present investigation was undertaken to study the production performance in a singlet and twin kid bearing Surti goats. The milk yield in twin bearing goats was significantly $(\mathrm{P}<0.01)$ higher on $7(528.57 \pm 31.99$ Vs $314.28 \pm 58.84), 15(714.28 \pm 40.40$ Vs $414.28 \pm 50.84), 30(500 \pm 92.58$ Vs $314.28 \pm 40.40)$ day of kidding. Udder length $(40.00 \pm 0.53$ Vs $35.57 \pm 1.32)$ in doe was significantly higher $(\mathrm{P}<0.05)$ in twin bearing goats on 45 days of kidding. Other udder parameters were also higher in twin but it was not significant. The result shows the udder development and milk production higher in twin bearing doe hence value also related to parity.

\section{Introduction}

India has witnessed a white revolution during the seventies which attributed to manifold increase in milk production. India is at number one in milk production. However, the productivity of India is still very low as compared to developed countries. Total registered breed of goat in India is 34 (NABGAR, 2018). India ranks second in goat population. The total population of goat in India is 135.17 (GOI, 2012-13). The production and reproduction performance of various Indian goat breeds were described in 
details but it is scanty on Surti goats in its breeding tract. (Ahmed et al., 2007; Alam et al., 2008; Lawar et al., 2008; Rao et al., 2009; Singh et al., 2009). An increasing number of corpora lutea may contribute more release of estrogen and progesterone secretion, which lead to stimulation of mammary gland development in goat bearing twin kid. In sheep also increase in litter size related to a rise in progesterone and better mammary development (Butler et al., 1981). Low conditioned ewe can induce deleterious effects on fetal and newborn lambs by adversely affecting placental size, fetal growth, deposition of fetal fat reserves for use after birth, maternal udder development and colostrums and milk production (Mellor, 1983; Mellor, 1988).

Scanty reports are available on Milk production concerning variation in size and shape of the udder. Also, very few studies carried out on Surti breed of goat. In view of the need to address these researchable issues in a holistic manner, it is designed to critically examine the change in morphology of udder related with milk production especially for singlet and twin kid bearing Surti goat.

\section{Materials and Methods}

The present study was conducted in the Department of Livestock Production and Management. The experimental animals were maintained at Livestock Research Station, Navsari Agricultural University, Navsari. Navsari is geographically located at an altitude of $11.89 \mathrm{M}$ above mean sea level, at a latitude of $20^{\circ} 57^{\prime} 0^{\prime \prime}$ north and longitude of $72^{\circ} 54^{\prime} 0^{\prime \prime}$ east. The research was carried out on 14 Surti goats after kidding and grouping of the dams based on singlet and twin kid birth of 7 each. Udder biometry was taken with measuring tape. Udder height, udder circumference, udder width and udder length were measured on $0,7,15,30,45$ and 60 days of postpartum.
Milk was collected on $0,7,15,30,45$ and 60 days. Data were analyzed using correlation, ttest and DMRT for comparison of a mean as per standard statistical procedures (Snedecor and Cochran, 1994).

\section{Results and Discussion}

The results of the change in milk yield/day have been presented in Table 1. The mean values of singlet bearing group were $485.71 \pm 98.63,314.28 \pm 58.84,414.28 \pm 50.84$, $314.28 \pm 40.40, \quad 285.71 \pm 67.00 \quad$ and $228.57 \pm 47.38$ on $0,7,15,30,45$ and 60 day after parturition respectively. The mean values of milk production in twin bearing group were $628.57 \pm 99.31, \quad 528.57 \pm 31.99, \quad 714.28 \pm 40.40$, $500 \pm 92.58,285.71 \pm 85.71$ and $444.28 \pm 76.93$ on $0,7,15,30,45$ and 60 day after parturition respectively. Goats that produced twin yielded more milk and had longer lactation (Carnicella et al., 2008) length. Does with multiple kids produced more milk than those with single kids was also reported by Hassan et al., (2010). This data are shown in table 1.

The mean values of Udder length in Surti doe was significantly higher $(\mathrm{P}>0.05)$ in twin bearing goats on 45 days of parturition as compared to a singlet. While comparing within-group the mean values of udder length were similar on all test days of parturition in singlet and twin group. Overall udder length varies from 35.35 to $37.35 \mathrm{~cm}$. The mean values of udder circumference in Surti doe did not differ significantly $(\mathrm{P}>0.05)$ between singlet and twin group though it was higher in twin group. The mean values of udder circumference in Surti doe were similar on all test day of parturition in singlet and twin group. Overall udder circumference varies from 35.14 to $37.07 \mathrm{~cm}$. The mean values of udder depth in Surti doe did not differ significantly $(\mathrm{P}>0.05)$ between singlet and twin group although it was higher in the twin group. While comparing within-group the 
mean values of udder depth were similar on all test days of parturition in singlet and twin group. Overall udder depth varies from 32.71 to $34.57 \mathrm{~cm}$. The mean values of udder width in Surti doe did not differ significantly (P>0.05) between singlet and twin group, Mean values of udder width were higher in twin as compared to singlet group on $7,15,30$ and 45 days of kidding.

While comparing within-group the mean values of udder width significantly differ on 7 and 60 days of parturition in singlet group.similar mean values of udder width were observed on 7, 15, 30 and 45 day; 0 and 60 days of parturition in singlet group. However, in twin, the similar mean values of udder width on 15, 30, 45 and 60 days of parturition were observed. Overall udder width varies from 10.28 to $11.42 \mathrm{~cm}$.
Udder morphological characters are important indicators of milk production potential as several studies have attempted to estimate the relationship. Even a prediction equation has been developed for milk yield estimation using different morphological udder measurements in goat by Akporhuarho et al., (2010). Upadhyay et al., (2014) claimed higher udder volume in multiparous animals might be due to complete growth and active phase of the mammary system with advancement of parity. The present results were in agreement with Gall (1980) who found that udder volume increased with parity.

Further, parity also significantly affected the average daily milk yield (ADMY) and total milk yield (TMY). Conversely, Amao et al., (2003) concluded that parity had no significant effect on udder traits.

\begin{tabular}{|c|c|c|c|c|c|c|c|}
\hline \multicolumn{8}{|c|}{ Table.1 Results of change in milk yield/day } \\
\hline Parameters & Groups & 0 (Day) & 7 & 15 & 30 & 45 & 60 \\
\hline \multirow{2}{*}{$\begin{array}{l}\text { Milk yield } \\
\text { (gm) }\end{array}$} & Singlet & $485.71 \pm 98.63^{b}$ & $314.28 \pm 58.84^{\mathrm{a} \mathrm{b}^{* *}}$ & $414.28 \pm 50.84^{\mathrm{b}^{* *}}$ & $314.28 \pm 40.40^{\mathrm{ab}^{* *}}$ & $285.71 \pm 67.00^{\mathrm{ab}}$ & $228.57 \pm 47.38^{\mathrm{a}}$ \\
\hline & Twin & $628.57 \pm 99.31^{\mathrm{ab}}$ & $528.57 \pm 31.99^{a b^{* *}}$ & $714.28 \pm 40.40^{\mathrm{b}^{* *}}$ & $500 \pm 92.58^{\mathrm{ab} * *}$ & $285.71 \pm 85.71^{\mathrm{a}}$ & $444.28 \pm 76.93^{\mathrm{ab}}$ \\
\hline
\end{tabular}

Table.2 Udder morphological characters

\begin{tabular}{|c|c|c|c|c|c|c|c|}
\hline \multirow[t]{2}{*}{ Parameters } & \multirow[t]{2}{*}{ Groups } & \multicolumn{6}{|c|}{ Days } \\
\hline & & 0 & 7 & 15 & 30 & 45 & 60 \\
\hline \multirow{3}{*}{$\begin{array}{l}\text { Udder length } \\
\text { (Cm) }\end{array}$} & Singlet & $32.28 \pm 1.40^{\mathrm{a}}$ & $32.71 \pm 1.26^{\mathrm{a}}$ & $34.14 \pm 1.12^{\mathrm{a}}$ & $34.14 \pm 1.35^{\mathrm{a}}$ & $34.57 \pm 1.32^{\mathrm{a}^{*}}$ & $34.14 \pm 1.40^{\mathrm{a}}$ \\
\hline & Twin & $40.42 \pm 0.42^{\mathrm{a}}$ & $38.00 \pm 0.37^{\mathrm{a}}$ & $39.57 \pm 0.61^{\mathrm{a}}$ & $39.57 \pm 0.42^{\mathrm{a}}$ & $40.00 \pm 0.53^{\mathrm{a}^{*}}$ & $40.42 \pm 0.57^{\mathrm{a}}$ \\
\hline & Over all & $37.35 \pm 1.10$ & $35.35 \pm 0.99$ & $36.85 \pm 0.97$ & $36.85 \pm 1.01$ & $37.28 \pm 1.01$ & $37.28 \pm 1.13$ \\
\hline \multirow{3}{*}{$\begin{array}{l}\text { Udder } \\
\text { circumference } \\
(\mathrm{Cm})\end{array}$} & Singlet & $35.14 \pm 1.10^{\mathrm{a}}$ & $33.71 \pm 1.12^{\mathrm{a}}$ & $34.71 \pm 1.04^{\mathrm{a}}$ & $34.85 \pm 1.07^{\mathrm{a}}$ & $34.85 \pm 1.07^{\mathrm{a}}$ & $35.85 \pm 1.07^{\mathrm{a}}$ \\
\hline & Twin & $39.16 \pm 0.98^{a}$ & $36.57 \pm 0.89^{\mathrm{a}}$ & $37.28 \pm 0.86^{\mathrm{a}}$ & $37.28 \pm 0.86^{\mathrm{a}}$ & $37.28 \pm 0,86^{\mathrm{a}}$ & $38.28 \pm 0.86^{\mathrm{a}}$ \\
\hline & Over all & $37.00 \pm 085$ & $35.14 \pm 0.79$ & $36.00 \pm 0.74$ & $36.07 \pm 0.74$ & $36.07 . \pm 0.74$ & $37.07 \pm 0.74$ \\
\hline \multirow{3}{*}{$\begin{array}{l}\text { Udder depth } \\
\text { (Cm) }\end{array}$} & Singlet & $33.42 \pm 1.23^{\mathrm{a}}$ & $31.71 \pm 1.18^{\mathrm{a}}$ & $33.14 \pm 1.12^{\mathrm{a}}$ & $34.85 \pm 1.07^{\mathrm{a}}$ & $33.00 \pm 1.04^{\mathrm{a}}$ & $33.07 \pm 1.04^{\mathrm{a}}$ \\
\hline & Twin & $35.71 \pm 0.71^{\mathrm{a}}$ & $33.71 \pm 1.04^{\mathrm{a}}$ & $35.00 \pm 0.97^{\mathrm{a}}$ & $37.28 \pm 0.86^{\mathrm{a}}$ & $34.28 \pm 0.52^{\mathrm{a}}$ & $35.57 \pm 0.81^{\mathrm{a}}$ \\
\hline & Over all & $34.57 \pm 0.75$ & $32.71 \pm 0.80$ & $33.07 \pm 0.75$ & $33.64 \pm 0.58$ & $33.64 \pm 0.58$ & $34.57 \pm 0.69$ \\
\hline \multirow{3}{*}{$\begin{array}{l}\text { Udder Width } \\
\text { (cm) }\end{array}$} & Singlet & $11.42 \pm 0.52^{\mathrm{bc}}$ & $10.14 \pm 0.40^{\mathrm{a}}$ & $11.14 \pm 0.40^{\mathrm{abc}}$ & $10.28 \pm 0.28^{\mathrm{ab}}$ & $10.28 \pm 0.28^{\mathrm{ab}}$ & $11.57 \pm 0.36^{\mathrm{c}}$ \\
\hline & Twin & $11.14 \pm 0.34^{\mathrm{a}}$ & $10.42 \pm 0.48^{\mathrm{a}}$ & $11.28 \pm 0.48^{\mathrm{a}}$ & $10.28 \pm 0.35^{\mathrm{a}}$ & $10.28 \pm 0.35^{\mathrm{a}}$ & $11.28 \pm 0.35^{\mathrm{a}}$ \\
\hline & Over all & $11.28 \pm 0.30$ & $10.28 \pm 0.30$ & $11.21 \pm 0.28$ & $10.28 \pm 0.22$ & $10.28 \pm 0.22$ & $11.42 \pm 0.25$ \\
\hline
\end{tabular}




\begin{tabular}{|l|l|l|}
\hline \multicolumn{3}{|c|}{ Table.3 Effect of parity on singlet and twin kid bearing Surti goats } \\
\hline \multicolumn{1}{|c|}{ Pattern of kidding } & Mean \pm S.E of Parity & \multicolumn{1}{c|}{ P-value } \\
\hline Singlet & $1.00 \pm 0.00^{*}$ & 0.04 \\
\hline Twin & $3.85 \pm 0.63^{*}$ & \\
\hline
\end{tabular}

Similar to present result Kala and Prakash (1990) found peak yield in the third week period in Jamunapari goats. Rout et al., (1999) reported that Jamunapari can produce 4.9 liters of milk daily with average lactation yields 1.5 liters/day.

Milk yields increased up to the end of two months and then started to decline with an average lactation length of 260 days. The peak milk during the 4th week was reported by Louca et al., (1975) in Damascus goats followed by a steady decline.

The daily milk yield was different between stages of lactation. This supported Strzalkowska et al., (2009).

Similar to our result Laes-Fettback and Peters (1995) evaluated three Egyptian goat breeds like Baladi, Zaraibi and Damascus and concluded that all the three breeds had high persistency with a slightly higher yield during the initial part of lactation in Zaraibi and Damascus

Effect of parity on a singlet and twin bearing goat have been presented in Table 3 . Twinning was significantly $(\mathrm{P}<0.05)$ higher in multiparous goat as compared to a uni-parous goat.

In the present experiment all the singlet kid bearing goats were of first parity and 6 animals of twin kid bearing goats were multiparous and one goat was a uni-parous category.

The milk yield in twin bearing goats was significantly $(\mathrm{P}<0.01)$ higher on 7,15 and 30 days of parturition as compared to singlet bearing Surti does. The mean values of milk yield decreased after 15 days of parturition in both singlet and twin bearing group. Udder length in doe was significantly higher $(\mathrm{P}>0.05)$ in twin bearing on 45 days of parturition as compared to the singlet, the bearing does. Udder characteristics of twin bearing Doe were higher compared to single bearing doe. Consequently, their udder characteristics were more developed than singlet bearing doe. Mammary growth and development increased with parity number.

\section{References}

Ahmed, M., Singh, P. K., Sadana, D. K., Alam, S. and Chahal, D. (2007). Reproductive performance of Beetal goats in its breeding tract. Indian Journal of Small Ruminants, 13: 182-185.

Akporhuarho, P. O., Orheruata, J. A., Otoikhian, C. S. O. and Igene, F.U. (2010). Evaluation of udder size and milk yield of white bornu (W.B) goats reared under on-field research environment. Journal of Natural and Applied Sciences, 11: 1-6

Alam, S., Singh, P. K. and Khan, B. U. (2008). Performance evaluation of Beetal goats in its native tract. Indian Veterinary Journal, 85: 640-642.

Amao, O. A., Osinowo, O. A., Lakpini, C. A. M., Dipeolu, M. A., Abiola, S. S. and Onwuka, C. F. I. (2003). Type and frequency of udder shapes and abnormality in West African dwarf and Red skoto goat. Nigerian Journal of Animal Science, 30: 253-258.

Butler, W. R., Fullen Kamp, S. M., Capiello, L. A. and Handwerger, S. (1981). The relationship between breed and litter size in sheep and maternal serum concentration of placental lactogen, estradiol and progesterone. Journal of Animal Science, 53: 1077-1081.

Carnicella, D., Maria, M.D., Ayres, C.C., 
Laudadio V. and Dario, C. (2008). The effect of diet, parity, year and number of kids on milk yield and milk composition in Maltese goat. Small Ruminant Research, 77: 71-74.

D. Upadhyay, B.H.M. Patel, S. Kerketta, S. Kaswan, S. Sahu, Bharat Bhushan and T. Dutt (2014). Study on udder morphology and its relationship with production parameters in local goats of Rohilkhand region of India. Indian Journal of Animal Research, 48(6): 615-619.

Gall, C. (1980). Relationship between body conformation and production in dairy goats. Journal of Dairy Science, 63: 1768-1781.

Hassan, M. R., Talukder, M. A. I. and Sultana, S. (2010). Evaluation of the production characteristics of the Jamunapari goat and its adaptability to farm conditions in Bangladesh. Bangladesh Veterinarian, 27: 26-35.

Kala, S.N., Prakash, B. (1990). Genetic and phenotypic parameters of milk yield and milk composition in two Indian goat breeds. Small Ruminant Research, 3: 475- 484.

Laes-Fettback, C. and Peters, K.J. (1995). A comparative study of the performance of Egyptian goat breeds 1. Reproductive and dairy performance. Arch. Tierz. Dummerstorf, 38: 93-102.

Louca, A., Mavrogenis, A., Lawlor, M.J. (1975). The effects of early weaning on the lactation performance of Damascus goats and the growth rate of the kids. Animal Production, 20: 213-218

Mellor, D. J. (1983). Nutritional and placental determinants of fetal growth rate in sheep and consequences for the newborn lamb.
British Veterinary Journal, 139: 307-324.

Mellor, D. J. (1988). Integration of perinatal events, pathophysiological changes and consequences for the newborn lamb. British Veterinary Journal, 144: 552-569.

P. K., Mandal, A., Roy, R. and Singh, L. B. (1999). Improvement and conservation of Jamunapari goats in their home tract. India, Ministry of Agriculture Report, New Delhi, India.

Rao, P. K., Dash, S. K., Singh, M. K., Rai, B. and Singh, N. P. (2009). Ganjam goat of Orissa and its management practices. Indian Journal of Small Ruminant, 15: 44-50.

Rout, P. K., Mandal, A., Roy, R. and Singh, L. B. (1999). Improvement and conservation of Jamunapari goats in their home tract. India, Ministry of Agriculture Report, New Delhi, India.

Singh, M. K., Rai, B., Kumar, A., Sisodiya, H. S. and Singh, N. P. (2009). Production performance of Gohilwadi goats under range conditions. Indian Journal of Animal Science, 79: 587- 593.

Snedecor, G. W. and Cochran, W. G. (1994). Statistical Methods. 8th edn., Affiliated East-West Press, New Delhi Iowa State University Press, Iowa.

Strzalkowska, N., Jozwik, A., Bagnicka, E., Krzyzewski, J., Horbanczuk, K., Pyzel, B., and Horbanczuk, J.O. (2009). Chemical composition, physical traits and fatty acid profile of goat milk as related to the stage of lactation. Animal Science Papers and Reports volume, 28(4): 389-395.

\section{How to cite this article:}

Krishna C. Gamit, T.K.S. Rao, B.J. Thakre, V.V. Gamit and Patel, A.S. 2019. Udder Morphology Relationship with Milk Yield In Singlet and Twins Bearing Surti Goat. Int.J.Curr.Microbiol.App.Sci. 8(08): 1484-1488. doi: https://doi.org/10.20546/ijcmas.2019.808.173 